Article

\title{
Spatial Equity of Public Parks: A Case Study of Kabul City, Afghanistan
}

\author{
Rashid A. Mushkani ${ }^{1,2, *(D)}$ and Haruka Ono ${ }^{1}$ (D) \\ 1 Department of Architecture and Civil Engineering, Toyohashi University of Technology, \\ 1-1 Hibarigaoka Tempaku-cho, Toyohashi, Aichi 441-8580, Japan; ono.haruka@ace.tut.ac.jp \\ 2 Kabul Engineering Faculty, Kabul University, Kabul 1006, Afghanistan \\ * Correspondence: rashid.mushkan@ku.edu.af
}

check for updates

Citation: Mushkani, R.A.; Ono, $\mathrm{H}$. Spatial Equity of Public Parks: A Case Study of Kabul City, Afghanistan.

Sustainability 2021, 13, 1516.

https://doi.org/10.3390/su13031516

Academic Editor: Tiziana Campisi

Received: 23 December 2020

Accepted: 26 January 2021

Published: 1 February 2021

Publisher's Note: MDPI stays neutral with regard to jurisdictional claims in published maps and institutional affiliations.

Copyright: (c) 2021 by the authors. Licensee MDPI, Basel, Switzerland. This article is an open access article distributed under the terms and conditions of the Creative Commons Attribution (CC BY) license (https:/ / creativecommons.org/licenses/by/ $4.0 /)$.

\begin{abstract}
Accessibility, the size of the land area, the design and build quality, and the number of parks and their correlation with population density are key elements in fostering ecological spatial equity within cities. This study analyzed different spatial equity attributes of existing parks in Kabul City using onsite observations, measurement analyses, and mapping and buffering of satellite imagery using computer-aided design methods. The results revealed that, presently, 309 ha of urban land is covered by parks, which accounts for $0.78 \%$ of the total land area of $394.78 \mathrm{~km}^{2}$. On average, a quarter of city residents can access a park with basic amenities within 300 to $600 \mathrm{~m}$ of their residence, and parks currently provide a land coverage distribution per resident of $0.69 \mathrm{~m}^{2}$. However, the majority of parks lack certain amenities like playground and sports facilities desired by different user groups. This article also explored the inequitable distribution of parks at the city scale, underlining the scarcity or concentration of parks in certain areas and stressing the importance of allocating additional land for park provision.
\end{abstract}

Keywords: public parks; spatial equity; accessibility; Kabul City

\section{Introduction}

Cities are sizeable human settlements; however, although they provide solace and prosperity for their residents, they also pose significant health and environmental risks [1,2]. Urban stress in cities adversely affects human health and is often associated with higher population and housing density, lack of green space, congestion, noise, air and water pollution, and various patterns of inner-city socioecological conditions [1-4]. Tackling various urban stressors caused by human isolation from nature, most importantly from green spaces, is commonly believed to be a multidimensional challenge that is directly related to numerous urban elements and their configuration, especially public green parks $[5,6]$. Thus, establishing and extending the green spaces within cities has long been studied and used as a tool to overcome or reduce threats to health $[7,8]$.

Urban public parks are considered critical landscape elements of towns and cities and offer several environmental and social benefits $[2,4,7,9]$. They sustain healthy ecosystems, deliver clean air and water, and accelerate natural resource conservation [9]. Parks not only play a significant role in a city's vitality and livability but also promote and foster increased health and living standards, resulting in better mental health and reduced stress levels for residents [6-9]. Additionally, parks provide multiple indirect health benefits, which can be manifested in the provision of opportunities for physical and social recreational activities $[10,11]$. Moreover, parks are defined as egalitarian city services that bind different socioeconomic classes of society while nurturing a sense of community and vitality [12].

Urban settings in different countries have significant inequalities in the distribution of physical infrastructure that affect residents' quality of life; for example, residents in historic quarters of Changting in China, Glasgow in the UK and Berlin in Germany suffer from lack of access to basic services such as transportation, health care, and green space [1,3,13-17]. 
The positive and negative aspects, i.e., the health risks from being distanced from nature and the benefits of being close to it, are not homogeneously distributed throughout major cities $[18,19]$. When looking at deprived urban areas within a city, it is easy to conclude that residents are at greater health risks from natural and manmade hazards, including natural disasters, pollution, noise, and traffic toxicity [20]. In these deprived areas, access to the natural ecosystem is limited, especially in terms of access to natural landscapes, and there is a disparity between high population density and the low coverage of green space $[3,5,7,13,15]$.

During the past three decades, the theme of spatial equity, which includes distribution, availability, and access to public resources, has received much attention in urban planning and urban design contexts [5]. Broadly, spatial equity refers to the equitable and equal distribution of facilities and services in a space at any scale according to density, i.e., from the small scale of a neighborhood to the large scale of a city [21], and it has been defined and measured in different ways, depending on the value systems of justice, fairness, and need [22]. A review of the relevant literature identified various methods of spatial equity measurement and quantification [23]; researchers usually measure spatial equity using horizontal and vertical approaches. Horizontal equity is the equal dissemination of resources to all social classes in a society, whereas vertical equity involves the dissemination of services corresponding to the requirements of each class [24,25]. Conversely, spatial equity can be defined as the reasonable expansion of land use in both social and economic contexts, and the equitable flow of services and goods from governing bodies [26]. Generally, spatial equity focuses on the spatial assessment of the distribution of urban amenities and the differences among the receipt of these facilities by various regions, whereas the opposite (inequity) denotes the inappropriate and inequitable distribution of resources to one particular group or region $[3,27,28]$.

Generally, studies on spatial equity involve measuring accessibility [29]. Spatial equity is used as an indicator to determine the attainment of equity by measuring geographical or physical ease of access/ease of use to the entire population of the study area, irrespective of where or how people live [22,30-38]. Furthermore, researchers such as Penchansky and Thomas [39] and Smith [40] believed that spatial equity requires the provision of equal access for all and is measured by the spatial proximity to basic public facilities, including hospitals, schools, and markets. In this view, access is perceived as a geographic or spatial distance. Many studies over the past few decades have focused on the provision of parks in city centers, whereas more recent investigations have explored and examined spatial inequalities between city centers and metropolitan areas in terms of the availability of and access to parks [41-45]. Moreover, discussing the psychological, cultural, and economic importance of urban public parks allows the access issue to be further conceptualized as a critical measure of equity [46].

Finally, the term urban public park usually refers to public open green spaces with playgrounds and seating areas [9]. For cities to attain spatial equity of their public parks, first and foremost, there must be enough parks, and sufficient land must be allocated for their provision $[2,3,27,28]$. In terms of accessibility and distribution within the wider city area, each resident must have equitable access $[6-8,15,18,26,28]$. With the abovementioned research progression in mind, this study was devised with the aim of exploring and assessing the spatial equity of public parks in the context of an expanding city. Hence, the main goal of this study is to identify the disparities related to the accessibility and provision of urban public parks in Kabul; specifically, to assess the distance from public parks to residential areas, explore agglomeration and the disordered distribution patterns of parks at a city scale, and determine the ratio of urban land allocated to parks per capita.

\section{Materials and Methods}

The capital city of Kabul has a cold, semi-arid climate and is the largest city in Afghanistan. It is located in the east of the country along the Kabul River and south of the Hindu Kush mountains. The city is divided into 22 precincts, with a total population 
of 4.4 million people living in 16 of those (precincts $1-13$ and 15-17). The 16 municipal precincts comprise $394.78 \mathrm{~km}^{2}$ of urban land, which is concentrated in the city's central districts, whereas the remaining 6 peripheral precincts comprise agricultural land and villages. This study focuses on the urban land concentrated in the city center.

Precinct 1 is located centrally as it embodies the Kabul Old City, which originated 3500 years ago and established its contemporary basic structure during the 1940s and 1950s [47]. Gradually, the Old City's surrounding areas have undergone urbanization by conversion of farmland to residential areas. Regions bordering the western to northwestern part of the city center are planned urban area based on the 1964-78 Master Plans. They encompass parts of precincts $2,3,5,10$, and 15 , and most of the precincts 4 and 11 ; small sections of precincts 7, 8, 16, and 17 also fall in this domain. In precincts 16 and 17 large-scale urban development occurred post-2001 based on the 1978 Master Plan. Almost all areas of precinct 6 were urbanized after 1919 prior to the 1964 Master Plan preparation. The residual areas in precincts 7, 9, and 10 and almost all areas of the precinct 13 have been converted to residential areas in past two decades; construction works are carried out without the legal permission and for sales purposes [48]. Rapid population increase reinforced the expansion of unplanned residential area in several precincts. Some settlements occupy public property and are found in both the city center and its surroundings areas, especially on the hilly areas designated by the 1978 Master Plan as woodlands [47]. Overall, looking at Kabul's urban character, an obvious pattern of political centrality prevails more than the hierarchical pattern in social, ecological, or economical centralities. This matrix along with the land-use classification according to function was established in the first Master Plan prepared for the city in 1964 [49]. Significant alterations materialized post-2001, and the proposed ecological land uses are now occupied by residential settlements [48].

Data collection in this study was carried out in two phases; the first phase comprised locating and measuring the land area of each park in the specified precincts using satellite images, whereas the second phase comprised onsite measurements and field observations for validating the first phase results and further analyzing the parks' amenities and immediate surroundings. Overall, the basic aim for two-phase data collection was nurturing the credibility and balancing the weaknesses for accurate information convergence [50].

Calculations in this study were based on 2017 satellite images of Kabul produced by Sentinel 2-A (resolution $10 \mathrm{~m}$, time series 2017-01-12 T06:12:19.671Z to T06:22:25.777Z and 2017-06-01 T06:15:10.373Z to T06:22:44.952Z) freely acquired from the European Space Agency (ESA) website, and broad sets of onsite measurement and unobtrusive observation with the help of one research assistant, which was carried out between March 2018 and August 2019 (early morning until evening on one weekday; days were defined by good weather) [50]. This phase was conducted by measuring 21 parks' land area using a tape meter for drawing preparation and assessing all 65 existing parks' amenities and related activities through observation; whereas the demographic data were taken from the updated 2020 census published by Afghanistan's National Statistics and Information Authority [51]. These three data resources were arranged and linked within a Geographic Information System (GIS) framework (ArcGIS 10.5). The density-related statistics and disparities in park provision yielded two spatial equity parameters; namely, the park coverage ratio per region's area and the park area per region's population. The relevant equations for one region (precinct 1 ) are as follows:

$$
\begin{aligned}
& \mathrm{PCA}_{1}=\mathrm{T}_{\mathrm{P} 1} / \mathrm{R}_{\mathrm{A} 1} \\
& \mathrm{PAP}_{1}=\mathrm{T}_{\mathrm{P} 1} / \mathrm{A}_{\mathrm{P} 1}
\end{aligned}
$$

where PCA is the park coverage ratio per precinct's area and PAP is the park area per capita (of the precinct's population) $\left(\mathrm{m}^{2}\right), \mathrm{T}_{\mathrm{P}}$ is the total area of the parks in the precinct $\left(\mathrm{m}^{2}\right), A_{P}$ is the precinct's population (number of people), and $R_{A}$ is the precinct's area $\left(\mathrm{m}^{2}\right)$. The PCA index, by combining the area of the existent parks in a precinct and dividing it to the precinct's surface area, denotes place-based equity, whereas the PAP index, by 
combining the area of the existent parks in a precinct and dividing it by the precinct's population, denotes population-based equity. The relevant distance from a resident's home to the park was measured to determine the accessibility of a park [30-37,52-55]. Two methods are commonly used to analyze accessibility within GIS: the Euclidian distance, and network analysis [56-58]. This study used a Euclidian distance analysis, which is the preferred approach utilized by previous researchers for spatial equity investigations and proposed by the World Health Organization as an accessibility indicator analysis for urban green space $[57,59]$. The method was applied to calculate a park's surrounding serviceability area per resident along with the overlapping serviceability areas of some parks. A park's serviceability area is presumed to include an offset area perpendicular to the park's peripheral boundary, which is usually a fair and acceptable walking distance. In this context, researchers often divide parks into four categories [60,61]:

1. District parks: covering more than $8000 \mathrm{~m}^{2}$ of land, the buffer radius can extend more than $750 \mathrm{~m}$ to the park's outer boundary.

2. Vicinity parks: covering 4000 to $8000 \mathrm{~m}^{2}$ of land, the buffer radius can extend from 650 to $750 \mathrm{~m}$ to the park's outer boundary.

3. Local parks: covering 4000 to $5000 \mathrm{~m}^{2}$ of land, the buffer radius can extend from 300 to $375 \mathrm{~m}$ to the park's outer boundary.

4. Neighborhood parks: covering less than $5000 \mathrm{~m}^{2}$ of land, the buffer radius can extend from 220 to $250 \mathrm{~m}$ to the park's outer boundary.

Furthermore, municipality officials propose three categories of parks: city, precinct, and neighborhood based on their visual characteristics, without the predefined criterions for park land area and serviceability radius. The World Health Organization mandated that each citizen should not be more than $300 \mathrm{~m}$ (linear distance) away from a park with an area between 0.5 and 1 ha [62]. This study used radius buffer distances of 300 and $600 \mathrm{~m}$ for neighborhood and city parks, respectively, to accommodate the differences in the sizes of land areas. For precinct parks, a variable buffer radius of between 300 and $600 \mathrm{~m}$ was used (average of $450 \mathrm{~m}$ ) (see Table 1 for details). Finally, a GIS buffering instrument was used to draw a buffer zone for each park that indicated the park's serviceability area based on the abovementioned categories and the amount of land coverage [33,34]. Using other software tools, the intersecting serviceability areas of various parks were then mapped. Consequently, the MS Excel and Autodesk AutoCAD software were used to present the study findings through tables and drawings.

Table 1. Classification of parks in Kabul City. Categories are proposed by The Greenery Department of Kabul Municipality, statistics are derived from the research.

\begin{tabular}{cccc}
\hline Category & Number of Parks & Area $\left.\mathbf{( m}^{\mathbf{2}}\right)$ & Serviceability Radius (m) \\
\hline Neighborhood park & 43 & 348,949 & 300 \\
Precinct park & 16 & 580,730 & 450 \\
City park & 6 & $2,164,924$ & 600 \\
\hline Total & 65 & $3,094,603$ & \\
\hline
\end{tabular}

\section{Results}

Kabul City has 65 functioning public parks occupying a total of 309 ha [63,64]. By adopting the previously discussed four categories of urban park area standards and The Greenery Department of Kabul Municipality proposal (see the results in Table 1), the three categories of this classification can be demonstrated. Figure 1 illustrates the location of existing parks in Kabul City's precinct plan. 


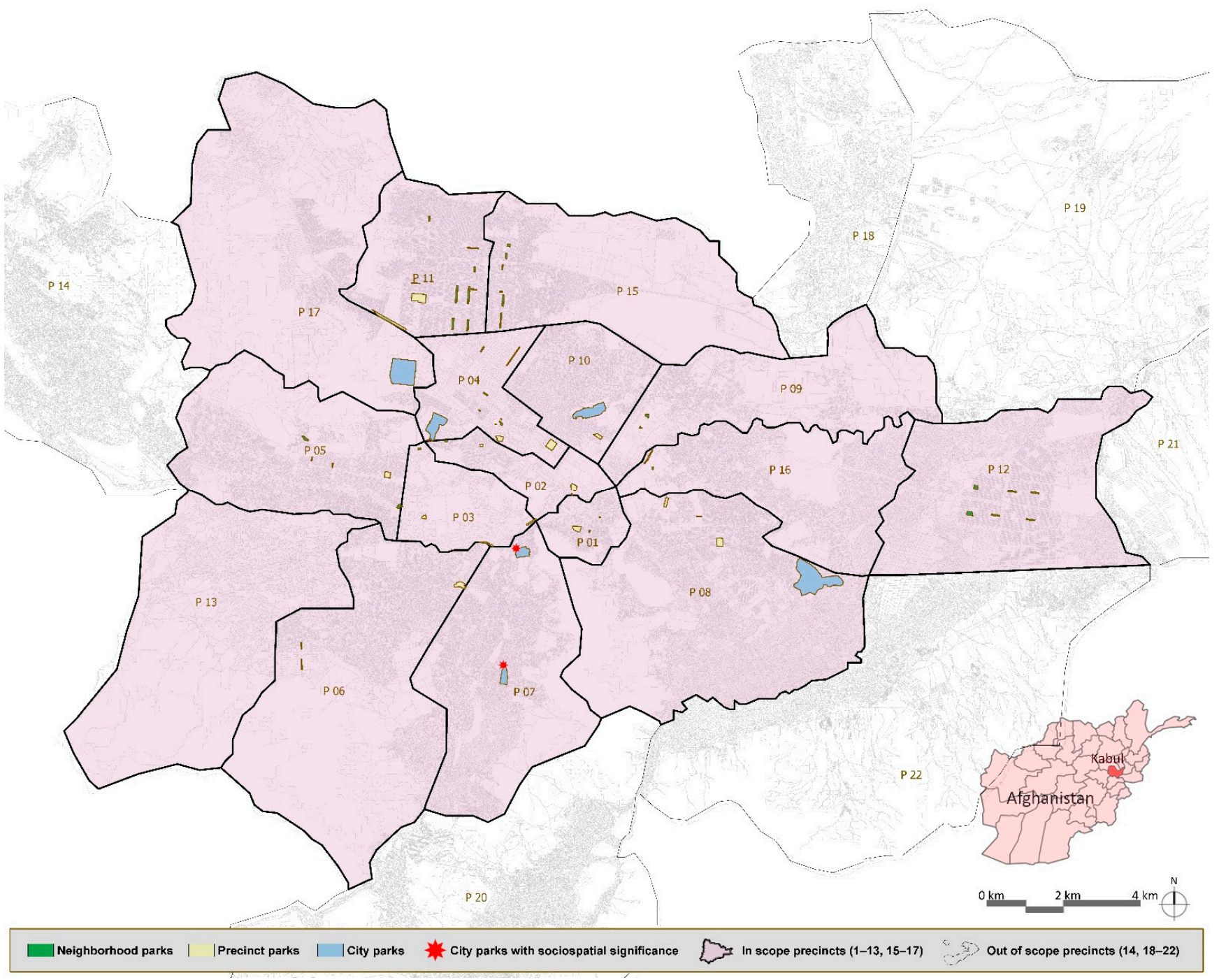

Figure 1. Kabul City precincts with existing public parks.

The findings suggest that presently in Kabul, $0.78 \%$ of urban land is covered by parks, occupying $3.09 \mathrm{~km}^{2}$ of a total urban land area of $394.78 \mathrm{~km}^{2}$. Furthermore, the city's parkland coverage distribution per capita is $0.69 \mathrm{~m}^{2}$. Comparing these figures with the international and regional park standards highlights the acute underprovision of parks in Kabul. For example, in major cities, the park area per resident is averaged at $10.2 \mathrm{~m}^{2}$ [64], which is more than 10 times that in Kabul (see Table 2). The World Health Organization suggests $9 \mathrm{~m}^{2}$ of green space per capita in a city for residents' quality of life and ecological sustenance [59]. The per capita statistics for precincts 1, 2, and 3 in the highly urbanized city center are $0.29,0.32$, and $0.28 \mathrm{~m}^{2}$, respectively. In these precincts, $0.73 \%, 0.68 \%$, and $0.53 \%$ of the total urban land are covered by parks, respectively.

Table 2. Park area per capita in different cities $\left(\mathrm{m}^{2}\right)$.

\begin{tabular}{cccccc}
\hline Region & Year & Park Area per Capita & Region & Year & Park Area per Capita \\
\hline Tokyo & 2020 & 5.73 & Berlin & 2018 & 11.67 \\
Seoul & 2019 & 4.38 & London & 2018 & 16.16 \\
New York & 2019 & 13.56 & Kabul & 2020 & 0.69 \\
\hline
\end{tabular}

Calculations of PCA and PAP in the municipality of Kabul yields that parks comprise $3.5 \%$ of the surface area of precinct 4 , giving it a slightly higher status than the other 
districts. In this precinct, the park area per capita is $1.1 \mathrm{~m}^{2}$. Conversely, only $0.08 \%$ of the total surface area of precinct 16 is covered by parks, and the park area per capita in this precinct is only $0.1 \mathrm{~m}^{2}$. Precinct 13 has insufficient provision of parks, and Table 3 presents further statistics.

Table 3. Park area, per capita area, land coverage, and precinct information.

\begin{tabular}{|c|c|c|c|c|c|c|c|}
\hline $\begin{array}{l}\text { Precinct } \\
\text { Number }\end{array}$ & $\begin{array}{c}\mathbf{R}_{\mathrm{A}} \text { (Precinct } \\
\text { Surface } \\
\text { Area) }\left(\mathrm{km}^{2}\right)\end{array}$ & $\begin{array}{c}\text { Precinct } \\
\text { Density } \\
\left(\text { Person } / \mathbf{k m}^{2}\right)\end{array}$ & $\begin{array}{l}A_{P} \text { (Precinct } \\
\text { Population) }\end{array}$ & $\begin{array}{c}\text { Total } \\
\text { Number of } \\
\text { Parks in } \\
\text { the } \\
\text { Precinct }\end{array}$ & $\begin{array}{l}T_{P} \text { (Total } \\
\text { Area of } \\
\text { Parks in } \\
\text { the Precinct) } \\
\text { (ha) }\end{array}$ & $\begin{array}{c}\text { PAP (Park } \\
\text { Area per } \\
\text { Capita) }\left(\mathrm{m}^{2}\right)\end{array}$ & $\begin{array}{c}\text { PCA } \\
\text { (Proportion of } \\
\text { Park Coverage } \\
\text { Area per } \\
\text { Precinct) (\%) }\end{array}$ \\
\hline 1 & 4.68 & 25,189 & 117,810 & 3 & 3.4 & 0.29 & 0.73 \\
\hline 2 & 6.77 & 21,179 & 143,303 & 4 & 4.6 & 0.32 & 0.68 \\
\hline 3 & 9.23 & 18,767 & 173,165 & 4 & 4.9 & 0.28 & 0.53 \\
\hline 4 & 11.6 & 31,753 & 369,455 & 10 & 40.6 & 1.10 & 3.50 \\
\hline 5 & 29.3 & 11,667 & 341,413 & 5 & 6.3 & 0.18 & 0.22 \\
\hline 6 & 49.1 & 7685 & 377,649 & 3 & 4.9 & 0.13 & 0.10 \\
\hline 7 & 32.6 & 13,875 & 451,758 & 2 & 22.0 & 0.49 & 0.67 \\
\hline 8 & 48.5 & 7750 & 375,646 & $\overline{4}$ & 89.8 & 2.39 & 1.85 \\
\hline 9 & 24.5 & 13,281 & 325,026 & 2 & 1.1 & 0.03 & 0.04 \\
\hline 10 & 13 & 30,663 & 398,589 & 2 & 28.3 & 0.71 & 2.18 \\
\hline 11 & 17.4 & 17,954 & 312,097 & 11 & 30.6 & 0.98 & 1.76 \\
\hline 12 & 34.8 & 1647 & 57,357 & 6 & 7.4 & 1.29 & 0.21 \\
\hline 13 & 46.7 & 5648 & 263,662 & 0 & 0.0 & 0.00 & 0.00 \\
\hline 15 & 32.1 & 13,267 & 426,448 & 6 & 5.4 & 0.13 & 0.17 \\
\hline 16 & 25.2 & 7353 & 185,183 & 2 & 1.9 & 0.10 & 0.08 \\
\hline \multirow[t]{2}{*}{17} & 56 & 2070 & 115,989 & 1 & 57.0 & 4.91 & 1.02 \\
\hline & $\begin{array}{c}\text { Total city } \\
\text { surface urban } \\
\text { area }=394.78 \\
\left(\mathrm{~km}^{2}\right)\end{array}$ & $\begin{array}{c}\text { Average density } \\
\text { in Kabul City = } \\
11,958 \\
\left(\text { people } / \mathrm{km}^{2} \text { ) }\right.\end{array}$ & $\begin{array}{c}\text { Total city } \\
\text { population }= \\
4.4 \text { (million } \\
\text { people) }\end{array}$ & $\begin{array}{c}\text { Total } \\
\text { number of } \\
\text { parks } \\
\text { citywide }=65\end{array}$ & $\begin{array}{l}\text { Total park } \\
\text { area } \\
\text { citywide = } \\
309 \text { (ha) }\end{array}$ & $\begin{array}{c}\text { Park area per } \\
\text { capita } \\
\text { citywide }= \\
0.69\left(\mathrm{~m}^{2}\right)\end{array}$ & $\begin{array}{c}\text { Proportion of } \\
\text { park coverage } \\
\text { area citywide = } \\
0.78(\%)\end{array}$ \\
\hline
\end{tabular}

Roughly, 20.5\% of Kabul's urban land area, accommodating 0.9 million people, is covered only by one to three park serviceability areas. The accessibility areas of two parks intersect with each other in $1.72 \%$ of the city's urban land, which is home to approximately one out of every 45 of the city's inhabitants. Roughly 3.54 million people of the city's total population do not live within the serviceability area of at least one park, whereas in other regions of the city, there is an overlap in the serviceability areas of four parks (see Tables 4 and 5 and Figure 2 for more details).

Table 4. Overlapping park serviceability areas in Kabul City.

\begin{tabular}{cccc}
\hline $\begin{array}{c}\text { Number of Overlapping Park } \\
\text { Serviceability Areas }\end{array}$ & Overlap Area $\left.\mathbf{( m}^{2}\right)$ & $\begin{array}{c}\text { Proportion of City Surface } \\
\text { Covered by Overlapping Parks (\%) }\end{array}$ & $\begin{array}{c}\text { Number of Residents in the } \\
\text { Overlapping Area (Persons) }\end{array}$ \\
\hline Two overlapping parks & 6781,543 & 1.72 & 81,094 \\
Three overlapping parks & 379,978 & 0.10 & 4544 \\
Four overlapping parks & 283,580 & 0.07 & 3391 \\
Five or more overlapping parks & & None & \\
\hline
\end{tabular}


Table 5. Park categories, serviceability area per category in different precincts, and number of residents with no access to park in Kabul City.

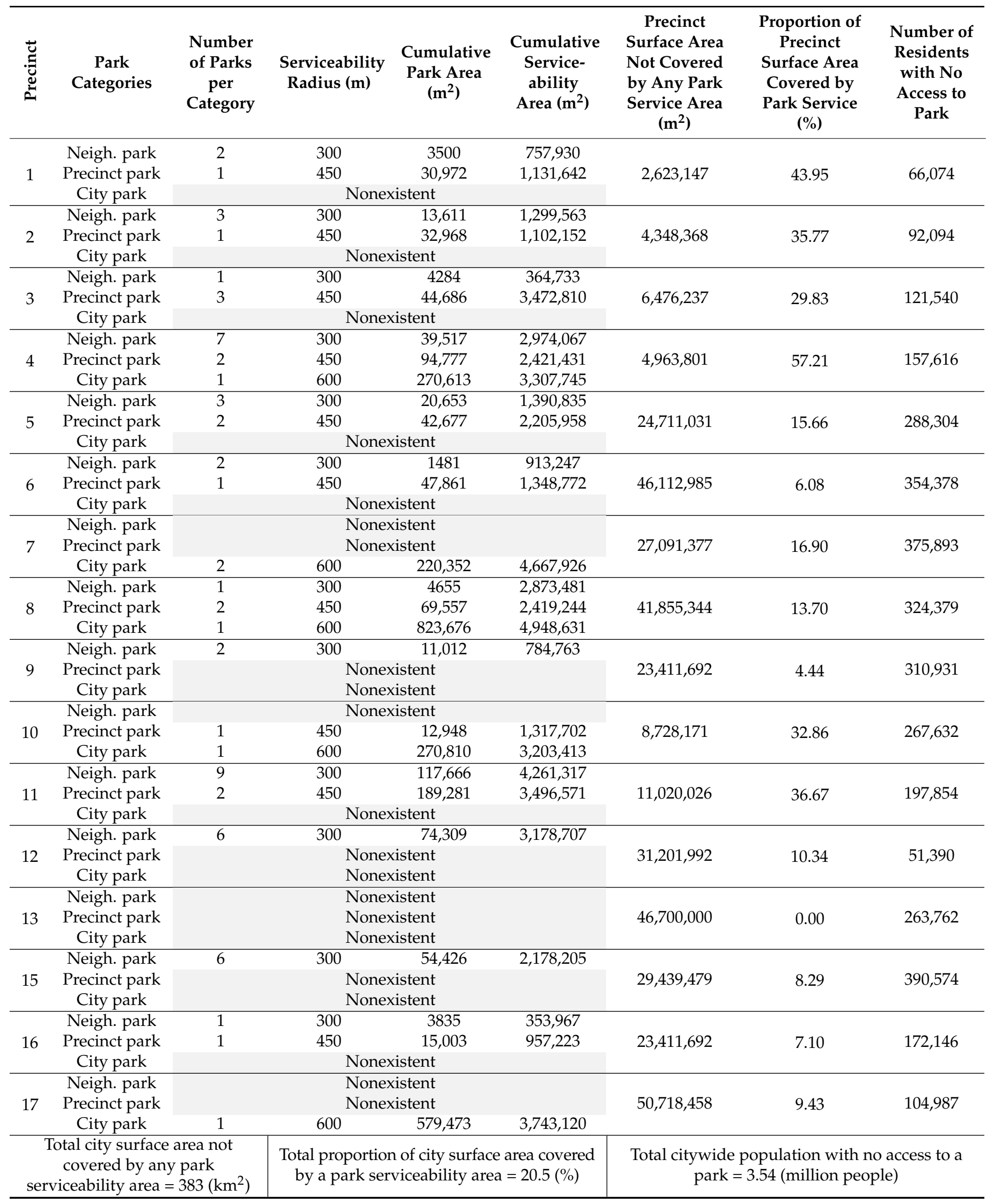




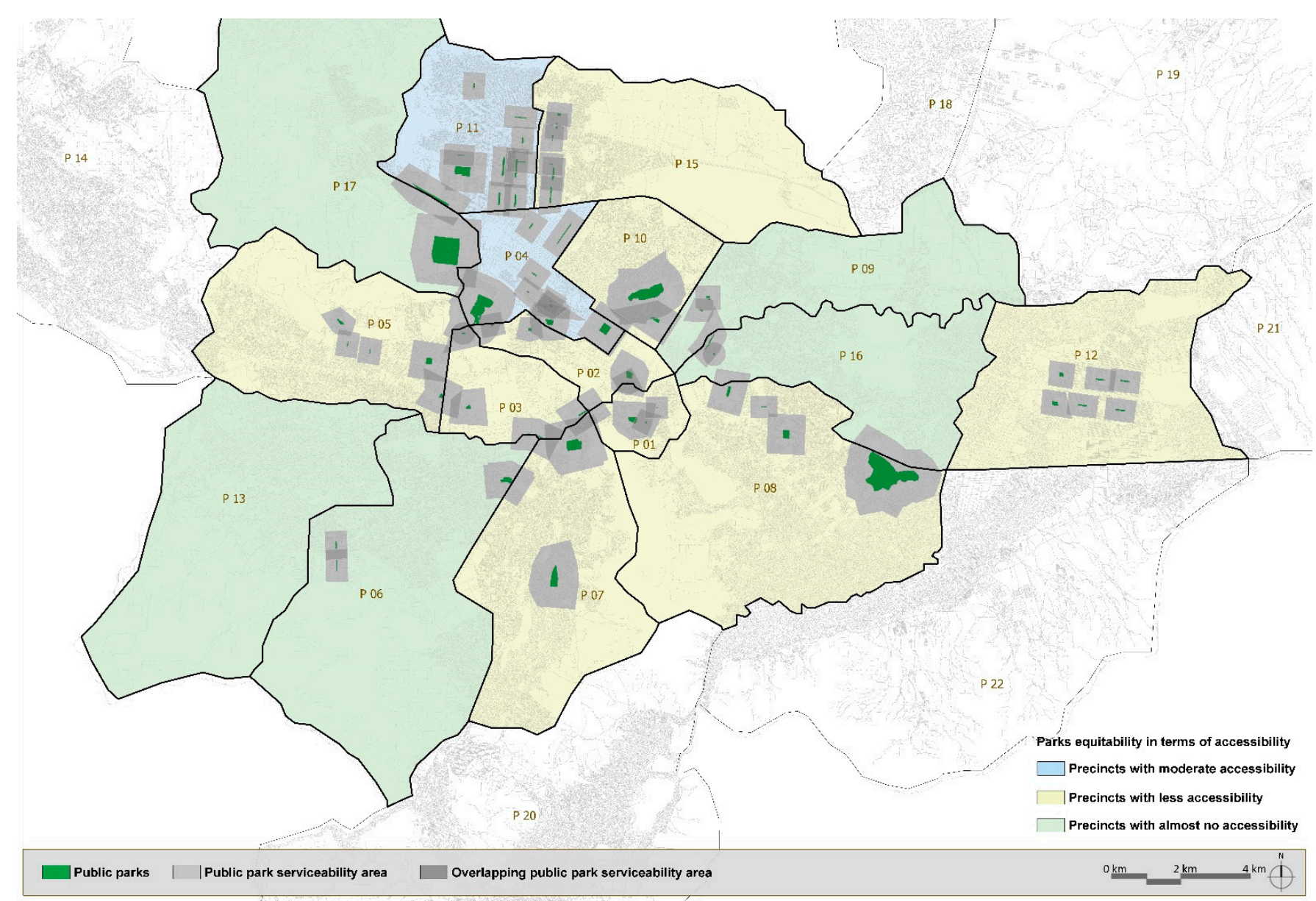

Figure 2. Park serviceability area coverage in Kabul City.

In the northern areas of the city (precincts 4 and 11), parks are distanced more equitably in terms of accessibility (Figure 2). Conversely, in the central, southern, and eastern parts of Kabul, most people live beyond the reach of a park serviceability area. Urban areas with the highest intersection of park serviceability buffer zones can be found in two distinct parts of the city's northern fringes. Overall, newly built neighborhoods and townships offer residents better access to public parks, which is also the case in precincts 4 and 11 .

This study further investigated park serviceability areas according to the buffers drawn around them (see Tables 4 and 5 for the data); the results reveal that in four precincts $(4,8,12$, and 17$)$, which house 0.92 million people (20.9\% of the city's total population), each individual potentially benefits from more than $1 \mathrm{~m}^{2}$ of park area. In more than half of the city's urban area, which contains more than $60 \%$ of the city's population, the land allocated for parks is approximately $0.5 \mathrm{~m}^{2}$ per capita, whereas in precincts 10 and 11 , more than $15 \%$ of the population that reside in more than $10 \%$ of the urban land area have approximately $1 \mathrm{~m}^{2}$ of park area per capita.

In precincts 4, 11, and 15, which are located in the northern parts of the city (Figure 2), a significant number of neighborhood parks are situated in close proximity, resulting in a high overlap of serviceability areas. Conversely, the existence of large parks in precincts 8 , 10 , and 17 contributes to a park area of between 0.7 and $4.91 \mathrm{~m}^{2}$ per capita.

On the other hand, looking at the possible barriers surrounding the parks, residents' access to 13 out of 43 neighborhood parks is affected by local streets; four of those are immediately surrounded by streets and the serviceability areas of the remaining nine are disjointed on one or two sides from residential buildings. Furthermore, there are access difficulties to 12 out of 16 precinct parks, of which eight are separated by arterial streets on one or two sides and the remaining four by the Kabul River. Moreover, there are a series of 
problems to get access to six city parks for a city resident while there is no means of public transport citywide, three of them are separated by arterial streets, one by a graveyard and the remaining two, which are historic gardens and have sociospatial significance, require buying tickets and are encircled by thick boundary walls [65].

\section{Discussion}

There are many parks in the city's northern districts. Precincts 1 to 3 in the southern and central areas are of early construction and belong to the old city quarters where parks are small, scarce, and far apart. These areas comprise two-stage developments: the old city, which dates back 3500 years, and the informal settlements, which underwent rapid unplanned urbanization after 2001 [47,48]. However, unlike the informal settlers, the residents of the old city have considered the allocation of land for parks. Alongside economic fluctuations, changes in the residents' socioeconomic status resulted in an unprecedented increase in land value [48]. Vacant land or land allocated for parks in the city's masterplan on which construction had not started was acquired legally or otherwise. A comparison between these areas and the northern quarters of the city suggests that gradual construction based on the 1964-78 City Masterplans has yielded better spatial equity in terms of parks. Another key factor in the underprovision of parks in the city center, western areas, and southern areas is the price and ownership of land; in these districts, public land is scarce, and land prices are up to 10 times higher than in other parts of the city. In Kabul's northern districts, the grid-based geometry has more free land parcels, allowing some to be allocated for parks.

Although unequal access is common and the park area proportion per capita is very low, inequalities in the spatial distribution of public parks across the city are also representative of the importance of spatial inequality. Kabul City is surrounded by mountains. Along with post-2001 political and socioeconomic stimulators, this geographical factor in conjunction with rapid urbanization contributed to higher land prices, whereas confusion and corruption in administrative and regulatory agencies have allowed unparalleled arbitrary and inequitable growth in the city [48,63].

This study significantly contributes to urban planning and sustainability literature in Afghanistan. By using simple methods of quantifying the size and accessibility of public parks within a GIS framework and correlating it with the census data, we measured residents' access to parks in different precincts to point out the spatial issue of inequitable distribution of urban public parks throughout the city. By doing so we combined patterns of place with population-based equity. The simplicity of the adopted methodology will make this study appealing to a broad category of researchers and urban planning institutions. However, there are limitations to the methodology: it does not allow spatial equity analysis based on consideration of the residents' socioeconomic status and different demographic categories.

Recently, numerous studies assessed the accessibility and functionality of urban parks $[3,19,21,44,45,52,66-70]$. Similarly, these studies demonstrated that the availability, access, and distribution of urban parks are deeply related to urban development patterns and geographical location. One study by Almohamad et al. [71] assessed the accessibility and spatial equity of public green spaces in the city of Aleppo, Syria, and found the same patterns of spatial inequities as those of Kabul, which affected residents' quality of life. These studies used complex methods of spatial analysis, however, they failed to address the access difficulties in parks' immediate surrounding areas. In our study, we used simple methods and attempted to expose the correlation between the number, accessibility and land area of urban public parks and the resident population at precinct level.

Furthermore, Kabul's urban governing body can use the results of this study to direct the city development course to a more equitable one. The park-deprived city regions which are recognized in this study can be addressed through the application of different urban initiatives such as land readjustment, urban redevelopment, urban upgrading, and land acquisition methods based on the precincts' urban character with the residents' and their 
communities' cooperation, which also requires further future research [72-75]. Moreover, providing public transport routes to the existing city parks can also ease accessibility problems while adding to the residents' quality of life [65].

\section{Conclusions}

Despite Kabul City's higher rainfall compared with those of other cities in Afghanistan, it remains disconnected from nature and suffers from a lack of urban public parks and open green spaces. The park area per capita figure in Kabul is significantly low when compared with those of similar spatial and economic regional and international cities, and the proportion of land allocated for parks is also low in terms of the city's population density.

The agglomeration of parks in the city's northern regions shows the inequitable nature of public park distribution and construction citywide. Four-fifths of the city's surface area and three-quarters of city residents do not fall within the serviceability area of any park. However, in $0.07 \%$ of urban land, there is an overlap in the serviceability areas of three parks. Among a total of 16 municipal precincts, precinct 4 occupies a noteworthy position, and precinct 13 has not even one park.

Finally, in Kabul City, the proportion of park coverage area per urban surface area is significantly low, and the city can be categorized among the most deprived cities in the world in terms of access to nature. Neighborhoods constructed before 2001 and more recently under the guidance of the city's third masterplan have created better access to parks than those built during the rapid urbanization of the previous two decades. This study highlighted that except for the northern regions of the city, all other districts, particularly precinct 13, have a critical need for land to be allocated for parks, and the construction of new parks should be the primary goal of the governing city planning body; however, when compared with other international cities and WHO standards, there is an obvious shortage of parks in prominent precincts. Moreover, further park spatial equity research, based on consideration of the residents' socioeconomic status and different demographic categories and urban governing bodies' action, is needed to foster spatial equity within Kabul city in the ecological domain.

Author Contributions: Conceptualization, R.A.M. and H.O.; methodology, R.A.M.; software, R.A.M.; validation, H.O.; formal analysis, R.A.M.; investigation, R.A.M.; resources, R.A.M.; data curation, R.A.M.; writing—original draft preparation, R.A.M.; writing—review and editing, H.O.; visualization, R.A.M.; supervision, H.O. All authors have read and agreed to the published version of the manuscript.

Funding: This research received no external funding.

Institutional Review Board Statement: Ethical review and approval were waived for this study, due to the fact that there was not any requisition or official demand for such a permission.

Informed Consent Statement: Informed consent was obtained from all subjects involved in the study.

Data Availability Statement: Publicly available datasets were analyzed in this study. This data can be found here: [https://earthexplorer.usgs.gov/L1C_T42SWD_A008139_20170112T061219 and https://nsia.gov.af/services].

Conflicts of Interest: The authors declare no conflict of interest.

\section{References}

1. Krefis, A.C.; Augustin, M.; Schluzen, K.H.; Obenbrugge, J.; Augustin, J. How Does the Urban Environment Affect Health and Well-Being? A Systematic Review. Urban Sci. 2018, 2, 21. [CrossRef]

2. Maas, J.; Verheij, R.A.; Groenewegen, P.P.; de Vries, S.; Spreeuwenberg, P. Green space, urbanity, and health: How strong is the relation? J. Epidemiol. Community Health 2006, 60, 587-592. [CrossRef] [PubMed]

3. Yuan, Y.; Xu, J.; Wang, Z. Spatial Equity Measure on Urban Ecological Space Layout Based on Accessibility of Socially Vulnerable Groups-A Case Study of Changting, China. Sustainability 2017, 9, 1552. [CrossRef]

4. Eizenberg, E.; Jabareen, Y. Social sustainability: A new conceptual framework. Sustainability 2017, 9, 68. [CrossRef]

5. Crook, V.A.; Andrews, G.J. Primary Health Care: People, Practice, Place; Ashgate Publishing: Surrey, UK, 2009. 
6. Coombes, E.; Jones, A.P.; Hillsdon, M. The relationship of physical activity and overweight to objectively measured green space accessibility and use. Soc. Sci. Med. 2010, 70, 816-822. [CrossRef] [PubMed]

7. Thompson, W.C.; Roe, J.; Aspinall, P.; Mitchell, R.; Clow, A.; Miller, D. More green space is linked to less stress in deprived communities: Evidence from Salivary Cortisol patterns. Landsc. Urban Plan. 2012, 105, 221-229. [CrossRef]

8. Rich, R.C. Neglected Issues in the Study of Urban Service Distributions: A Research Agenda. Urban Stud. 1979, 16, 143-156. [CrossRef]

9. Konijnendijk, C.C.; Annerstedt, M.; Nielsen, A.B.; Maruthaveeran, S. Benefits of Urban Parks: A Systematic Review; IFPRA: Copenhagen \& Alnarp, Denmark, 2013.

10. Kothencz, G.; Kolcsár, R.; Cabrera-Barona, P.; Szilassi, P. Urban Green Space Perception and Its Contribution to Well-Being. Int. J. Environ. Res. Public Health 2017, 14, 766. [CrossRef]

11. Weber, D.; Anderson, D. Contact with nature: Recreation experience preferences in Australian parks. Ann. Leis. Res. 2011, 13, 46-49. [CrossRef]

12. Loures, L.; Santos, R.; Panagopoulos, T. Urban Parks and Sustainable City Planning-The Case of Portimão, Portugal. WSEAS Trans. Environ. Dev. 2007, 10, 171-180.

13. Shen, J.; Cheng, J.; Huang, W.; Zeng, F. An Exploration of Spatial and Social Inequalities of Urban Sports Facilities in Nanning City, China. Sustainability 2020, 12, 4353. [CrossRef]

14. Kimpton, A. A spatial analytic approach for classifying greenspace and comparing greenspace social equity. Appl. Geogr. 2017, 82, 129-142. [CrossRef]

15. Guo, M.; Liu, B.; Tian, Y.; Xu, D. Equity to Urban Parks for Elderly Residents: Perspectives of Balance between Supply and Demand. Int. J. Environ. Res. Public Health 2020, 17, 8506. [CrossRef] [PubMed]

16. Nesbitt, L.; Meitner, M.J.; Girling, C.; Sheppard, S.R.J.; Lu, Y. Who has access to urban vegetation? A spatial analysis of distributional green equity in 10 US cities. Landsc. Urban Plan. 2019, 181, 51-79. [CrossRef]

17. Higgs, G.; Langford, M.; Norman, P. Accessibility to sport facilities in Wales: A GIS-based analysis of socio-economic variations in provision. Geoforum 2015, 62, 105-120. [CrossRef]

18. Sampson, R.J. Urban sustainability in an age of enduring inequalities: Advancing theory and ecometrics for the 21st-century city. Proc. Natl. Acad. Sci. USA 2016, 114, 8957-8962. [CrossRef]

19. Rigolon, A.; Browning, M.H.E.M.; Lee, K.; Shin, S. Access to Urban Green Space in Cities of the Global South: A Systematic Literature Review. Urban Sci. 2018, 2, 67. [CrossRef]

20. Kjellstrom, T.; Friel, S.; Dixon, J.; Corvalan, C.; Rehfuess, E.; Campbell-Lendrum, D.; Gore, F.; Bartram, J. Urban Environmental Health Hazards and Health Equity. J. Urban Health 2007, 84, 86-97. [CrossRef]

21. Tsou, K.W.; Hung, Y.T.; Chang, Y.L. An accessibility-based integrated measure of relative spatial equity in urban public facilities. Cities 2005, 22, 424-435. [CrossRef]

22. Hewko, J.N. Spatial Equity in Urban Environment: Assessing Neighborhood Accessibility to Public Amenities. Master's Thesis, University of Alabama, Tuscaloosa, AL, USA, 2001. [CrossRef]

23. Litman, T. Evaluating Transportation Equity. World Trans. Policy Prac. 2002, 8, 50-65.

24. He, S.; Wu, Y.; Wang, L. Characterizing Horizontal and Vertical Perspectives of Spatial Equity for Various Urban Green Spaces: A Case Study of Wuhan, China. Front. Pub. Health 2020, 8, 10. [CrossRef] [PubMed]

25. Murray, A.; Davis, R. Equity in regional service provision. J. Reg. Sci. 2001, 41, 557-560. [CrossRef]

26. Buhangin, J. Spatial equity: A parameter for sustainable development in indigenous regions. WIT Trans. Ecol. Environ. Sustain. Cities 2013, 1, 1343-1350. [CrossRef]

27. Dadashpoor, H.; Rostami, F.; Alizadeh, B. Is inequality in the distribution of urban facilities inequitable? Exploring a method for identifying spatial inequity in an Iranian city. Cities 2016, 52, 159-172. [CrossRef]

28. Dai, D.J. Racial/ethnic and socioeconomic disparities in urban green space accessibility: Where to intervene? Landsc. Urban Plan. 2011, 102, 234-244. [CrossRef]

29. Van, W.B. Accessible accessibility research challenges. J. Transp. Geogr. 2016, 51, 9-16. [CrossRef]

30. Luo, W.; Wang, F.H. Measures of Spatial Accessibility to health care in a GIS environment: Synthesis and a case study in the Chicago region. Environ. Plan. B 2003, 30, 865-884. [CrossRef]

31. Xiao, Y.; Wang, Z.; Li, Z.G.; Tang, Z.L. An assessment of urban park access in Shanghai-Implications for the social equity in urban China. Landsc. Urban Plan. 2017, 157, 383-393. [CrossRef]

32. Xing, L.J.; Liu, Y.F.; Liu, X.J. Measuring spatial disparity in accessibility with a multi-mode method based on park green spaces classification in Wuhan, China. Appl. Geogr. 2018, 94, 251-261. [CrossRef]

33. So, S.W. Urban Green Space Accessibility and Environmental Justice: A GIS-Based Analysis in the City of Phoenix, Arizona. Ph.D. Thesis, University of Southern California, Los Angeles, CA, USA, August 2016.

34. Gupta, K.; Roy, A.; Luthra, K.; Maithani, S. GIS based analysis for assessing the accessibility at hierarchical levels of urban green spaces. Urban For. Urban Green. 2016, 18, 198-211. [CrossRef]

35. Oh, K.; Jeong, S. Assessing the spatial distribution of urban parks using GIS. Landsc. Urban. Plan. 2007, 82, 25-32. [CrossRef]

36. Talen, E.; Anselin, L. Assessing spatial equity: An evaluation of measures of accessibility to public playground. Environ. Plan. 1998, 30, 595-613. [CrossRef]

37. Hansen, W.G. How Accessibility Shapes Land Use. J. Am. Inst. Plan. 1959, 25, 73-76. [CrossRef] 
38. Dolores Pitarch, M. Social Sustainability in Metropolitan Areas: Accessibility and Equity in the Case of the Metropolitan Area of Valencia (Spain). Sustainability 2018, 10, 371. [CrossRef]

39. Penchansky, R.; Thomas, J.W. The concept of access: Definition and relationship to consumer satisfaction. Med. Care 1981, 19, 127-140. [CrossRef]

40. Smith, D.M. Geography and Social Justice: Social Justice in a Changing World; Wiley-Blackwell Oxford: London, UK, 1994.

41. Moore, L.V. Availability of recreational resources in minority and low socioeconomic status areas. Am. J. Prev. Med. 2008, 34, 16-22. [CrossRef]

42. Comber, A.; Brunsdon, C.; Green, E. Using a GIS-based network analysis to determine urban greenspace accessibility for different ethnic and religious groups. Landsc. Urban Plan. 2008, 86, 103-114. [CrossRef]

43. Smoyer-Tomic, K.E.; Hewko, J.N.; Hodgson, M.J. Spatial accessibility and equity of playgrounds in Edmonton, Canada. Can. Geogr. 2004, 48, 287-302. [CrossRef]

44. Hoang, A.T.; Apparicio, P.; Pham, T.-T.-H. The Provision and Accessibility to Parks in Ho Chi Minh City: Disparities along the Urban Core-Periphery Axis. Urban Sci. 2019, 3, 37. [CrossRef]

45. Texier, M.I.; Schiel, K.; Caruso, G. The provision of urban green space and its accessibility: Spatial data effects in Brussels. PLoS ONE 2018, 13, e0204684. [CrossRef]

46. Lee, A.C.K.; Maheswaran, R. The health benefits of urban green spaces: A review of the evidence. Int. J. Public Health 2011, 33, 212-222. [CrossRef] [PubMed]

47. Japan International Cooperation Agency (JICA). Kabul City Current Status Report for Urban Development; RECS International Inc.: Tokyo, Japan, 2011.

48. Calogero, P.A. Planning Kabul: The politics of Urbanization in Afghanistan. Master's Thesis, University of California, Berkeley, CA, USA, 2011.

49. Beyer, E. Competitive coexistence: Soviet town planning and housing projects in Kabul in the 1960s. J. Arch. 2012, 17, 309-332. [CrossRef]

50. Yin, R.K. Case Study Research: Design and Methods, 5th ed.; Sage Publications: Thousand Oaks, CA, USA, 2013.

51. Central Statistic Organization (CSO). Population of Kabul City by district 2019-2020. Available online: https://nsia.gov.af/ services (accessed on 10 September 2020).

52. Zhang, X.; Lu, H.; Holt, J.B. Modeling spatial accessibility to parks: A national study. Int. J. Health Geogr. 2011, 10, 31. [CrossRef] [PubMed]

53. Herzele, V.; Wiedeman, T. A monitoring tool for the provision for accessible and attractive green spaces. Landsc. Urban Plan. 2003, 63, 109-126. [CrossRef]

54. Tian, Y.; Jim, C.Y.; Liu, Y. Using a Spatial Interaction Model to Assess the Accessibility of District Parks in Hong Kong. Sustainability 2017, 9, 1924. [CrossRef]

55. Nichollas, S.; Shafer, C.S. Measuring accessibility and equity in a local park system: The utility of geospatial technologies to park and recreation professionals. J. Park Recreat. Adm. 2001, 19, 102-124.

56. Goncalves, D.N.S.; Goncalves, C.M.; Assis, T.F.; Silva, M.A. Analysis of the difference between the Euclidean distance and the actual road distance in Brazil. Transp. Res. Pro. 2014, 3, 876-885. [CrossRef]

57. Reyes, M.; Praez, A.; Morency, C. Walking Accessibility to Urban Parks by Children: A case study of Montreal. Landsca. Urban Plan. 2014, 125, 38-47. [CrossRef]

58. Sander, H.A.; Ghosh, D.; Riper, D.V.; Manson, S. How do you measure distance in spatial models? An example using open-space valuation. Environ. Plan. 2010, 37, 874-894. [CrossRef]

59. World Health Organization (WHO). Urban. Green Spaces and Health: A Survey of Evidence; WHO: Geneva, Switzerland, 2016.

60. Sadeghian, M.M.; Vardanyan, Z. A Brief Review on Urban Park History, Classification and Function. Int. J. Sci. Tech. Res. 2015, 4, 120-124.

61. Ummeh, S.; Toshio, K. Classification of Urban Parks and their Regional Characteristics in Dhaka City, Bangladesh. J. Environ. Sci. Eng. 2017, 6, 41-54. [CrossRef]

62. World Health Organization (WHO). Urban. Green Spaces: A Brieffor Action; The WHO Regional Office for Europe: Copenhagen, Denmark, 2017.

63. Ufuq News Afghanistan. Available online: https://ufuqnews.com/archives/118581 (accessed on 12 August 2019).

64. Japan International Cooperation Agency (JICA). Draft Kabul City Master Plan; RECS International Inc.: Tokyo, Japan, 2011.

65. Liang, H.; Zhang, Q. Assessing the public transport service to urban parks on the basis of spatial accessibility for citizens in the compact megacity of Shanghai, China. Urban Studies 2017, 55, 1983-1999. [CrossRef]

66. Rigolon, A. A complex landscape of inequity in access to urban parks: A literature review. Landsc. Urban Plan. 2016, 153, 160-169. [CrossRef]

67. Huang, B.-X.; Chiou, S.-C.; Li, W.-Y. Accessibility and Street Network Characteristics of Urban Public Facility Spaces: Equity Research on Parks in Fuzhou City Based on GIS and Space Syntax Model. Sustainability 2020, 12, 3618. [CrossRef]

68. Timperio, A.F.; Ball, K.; Salmon, J.; Roberts, R.; Crawford, D. Is availability of public open space equitable across areas? Health Place 2007, 13, 335-340. [CrossRef] [PubMed]

69. Hashem, N. Assessing spatial equality of urban green spaces provision: A case study of Greater Doha in Qatar. Local Environ. 2015, 20, 386-399. [CrossRef] 
70. Tan, P.Y.; Wang, J.; Sia, A. Perspectives on five decades of the urban greening of Singapore. Cities 2013, 32, 24-32. [CrossRef]

71. Almohamad, H.; Knaack, A.L.; Habib, B.M. Assessing Spatial Equity and Accessibility of Public Green Spaces in Aleppo City, Syria. Forests 2018, 9, 706. [CrossRef]

72. Moseley, D.; Marzano, M.; Chetcuti, J.; Watts, K. Green networks for people: Application of a functional approach to support the planning and management of greenspace. Landsc. Urban Plan. 2013, 116, 1-12. [CrossRef]

73. Wright Wendel, H.E.; Zarger, R.K.; Mihelcic, J.R. Accessibility and usability: Green space preferences, perceptions, and barriers in a rapidly urbanizing city in Latin America. Landsc. Urban Plan. 2012, 107, 272-282. [CrossRef]

74. Haaland, C.; Bosch, C.K.V.D. Challenges and strategies for urban green-space planning in cities undergoing densification: A review. Urban For. Urban Green. 2015, 14, 760-771. [CrossRef]

75. Daniele, L.R.; Takatori, C.; Shimizu, H.; Privitera, R. A planning framework to evaluate demands and preferences by different social groups for accessibility to urban greenspaces. Sustain. Cities Soc. 2018, 36, 346-362. [CrossRef] 